\title{
PERTANGGUNGJAWABAN MUTLAK SEBAB KEBAKARAN LAHAN PERKEBUNAN MENGAKIBATKAN ANCAMAN SERIUS
}

\author{
Rony Andre Christian Naldo ${ }^{1}$, Mesdiana Purba ${ }^{2}$ \\ ${ }^{1,2}$ Fakultas Hukum, Universitas Simalungun \\ E-mail: ronyandre87@gmail.com ${ }^{1}$, mesdianapurba56@gmail.com ${ }^{2}$
}

\begin{abstract}
ABSTRAK
Lingkungan hidup merupakan bagian penting dari kehidupan, dan untuk itu setiap subjek hukum berkewajiban memelihara kelestarian fungsi lingkungan hidup dan menjaga keberlanjutan fungsi lingkungan hidup. Korporasi merupakan subjek hukum. Terkait dengan kewajiban aspek lingkungan hidup, dalam melakukan aktivitas bisnis perkebunan (kelapa sawit), sebagai subjek hukum, korporasi dilarang untuk membuka/mengolah lahan dengan cara membakar. Fakta di berbagai wilayah Indonesia, telah terjadi Perbuatan Melawan Hukum (PMH) berupa kebakaran lahan perkebunan berbagai korporasi yang mengakibatkan ancaman serius (pada akhirnya menimbulkan kerugian lingkungan hidup). Konsekuensi hukum dari PMH tersebut berupa pertanggungjawaban mutlak (strict liability) terhadap pelaku (korporasi) untuk membayar ganti rugi atas kerugian lingkungan hidup yang terjadi tanpa perlu pembuktian unsur kesalahan. Hasil pembahasan menyimpulkan bahwa konsep pertanggungjawaban mutlak sebab kebakaran lahan perkebunan mengakibatkan ancaman serius mencakup 13 (tiga belas) klausul hukum, yang masih mempunyai 4 (empat) hal kelemahan.
\end{abstract}

\section{Kata Kunci: Pertanggungjawaban Mutlak, Kebakaran, Ancaman Serius.}

\section{ABSTRACT}

The environment is an important part of life, and for that everyone shall be obliged to preserve the functions of environment and maintaining the sustainability of environmental functions. Corporation is a legal entity. Related to the obligation of environmental aspects, in carrying out plantation business activities (palm oil), as legal entity, corporations are prohibited to opening/processing land by fires. Facts in various regions of Indonesia, there has been a tort in the form of plantation land fires of various corporations which result in serious threats (which ultimately cause environmental losses). The legal consequences of the tort are strict liability for the perpetartor (corporation) to pay compensation for environmental losses that occur without the need to proof of elements of faults. The results of the discussion concluded that the concept of strict liability because of fire plantation land caused serious threats covering 13 (thirteen) legal clause, which still has 4 (four) things weakness.

Keywords: Strict Liability, Fires, Serious Threats.

\section{A. PENDAHULUAN}

Lingkungan hidup merupakan bagian penting bagi kehidupan manusia karena menyediakan berbagai macam kebutuhan ekonomi dan penunjang dalam memenuhi kebutuhan manusia untuk mempertahankan hidup. ${ }^{1}$ Pasal 33 ayat (3) dan (4) Undang-Undang

\footnotetext{
${ }^{1}$ Makmur Keliat et.al., 2016, Tanggung Jawab Negara, Friedrich Ebert Stiftung Kantor Perwakilan Indonesia, Jakarta, hlm. 126.
} 
Dasar Negara Republik Indonesia Tahun 1945 (UUD 1945) merupakan payung hukum pengelolaan lingkungan hidup di Indonesia.

Sebagai derivasinya, dibentuk peraturan perundang-undangan aspek lingkungan hidup yang mencakup perlindungan dan pengelolaan lingkungan hidup. Menurut Stefanus Munadjat Danusaputro, peraturan perundang-undangan yang berhubungan dengan aspek lingkungan hidup, disebut sebagai "hukum yang berwawasan penggunaan" sebab yang diatur adalah penggunaan unsur lingkungan, seperti tanah, air, hutan. ${ }^{2}$

Undang-undang lingkungan hidup telah 3 (tiga) kali mengalami pembaharuan. Pembaharuan terakhirnya adalah Undang-Undang Nomor 32 Tahun 2009 Tentang Perlindungan dan Pengelolaan Lingkungan Hidup (UU Nomor 32 Tahun 2009). ${ }^{3}$

UU Nomor 32 Tahun 2009, merupakan undang-undang pokok dalam aspek lingkungan hidup. Untuk itu semua peraturan perundang-undangan yang terkait dengan lingkungan hidup harus sesuai dan harmonis (sinkron secara vertikal maupun horizontal) dengan UU Nomor 32 Tahun 2009.

UU Nomor 32 Tahun 2009 yang merupakan wadah untuk menuangkan kebijaksanaan lingkungan hidup, diharapkan merupakan salah satu jalan keluar bagi masalah lingkungan hidup. Untuk tujuan tersebut, hukum dengan fungsinya sebagai sarana pembangunan dan rekayasa sosial dengan peranannya sebagai agen perubahan (agent of change) merupakan tumpuan harapan untuk terwujudnya pembangunan berkelanjutan, sebagaimana yang telah ditentukan pada Pasal 3 huruf i UU Nomor 32 Tahun 2009.

\footnotetext{
${ }^{2}$ M. Daud Silalahi, 2001, Hukum Lingkungan Dalam Sistem Penegakan Hukum Lingkungan Indonesia, Alumni, Bandung, hlm. 25.

Pembuatan hukum yang dilakukan secara sengaja oleh badan yang berwenang untuk itu merupakan sumber yang bersifat hukum yang paling utama. Kegiatan dari badan tersebut disebut sebagai kegiatan perundangundangan yang menghasilkan substansi yang tidak diragukan lagi kesalahannya, yang ipso jure. Tindakan yang dapat digolongkan kedalam kategori perundang-undangan ini cukup bermacam-macam, baik yang berupa penambahan terhadap peraturan-peraturan yang sudah ada, maupun yang mengubahnya. Hukum yang dihasilkan oleh proses seperti itu disebut sebagai hukum yang diundangkan (enacted law/statute law) berhadapan dengan hukum yang tidak diundangkan (unenacted law/common law). Orang Romawi menyebutnya "jus sriptum" dan "jus non scriptum". Suatu perundang-undangan menghasilkan peraturan yang memiliki 3 (tiga) ciri. Pertama, bersifat umum dan komprehensif, yang dengan demikian merupakan kebalikan dari sifat-sifat khusus yang terbatas. Kedua, bersifat universal. Ia diciptakan untuk menghadapi peristiwa-peristiwa yang akan datang, yang belum jelas bentuk konkritnya. Oleh karena itu ia tidak dapat dirumuskan untuk mengatasi peristiwa-peristiwa tertentu saja. Ketiga, ia memiliki kekuatan untuk mengoreksi dan memperbaiki dirinya sendiri. Adalah lazim bagi suatu peraturan mencantumkan klausul yang memuat kemungkinan dilakukannya peninjauan kembali. Dibandingkan dengan aturan kebiasaan, maka perundang-undangan memperlihatkan karateristik, suatu norma bagi kehidupan sosial yang lebih matang, khususnya dalam hal kejelasan dan kepastiannya. Hal ini tidak terlepas dari kaitannya dengan pertumbuhan negara sendiri. Aturan kebiasaan bisa dikatakan mengurusi hubungan antara orang dengan orang, sedang perundang-undangan antara orang dengan negara. Lihat Satjipto Rahardjo, 2006, Ilmu Hukum, Citra Aditya Bakti, Bandung, hlm. 83.

Bentuk perundang-undangan itu tidak akan muncul sebelum timbul pengertian negara sebagai pengemban kekuasaan yang bersifat sentral dan tertinggi. Lihat C.K. Allen, 1964, Law in the Making, Oxford University Press, New York, hlm. 410.

${ }^{3}$ Undang-undang lingkungan hidup merupakan dasar bagi peraturan pelaksanaannya baik tingkat pusat maupun daerah dari semua aspek lingkungan hidup. Undang-undang lingkungan hidup merupakan landasan untuk menilai dan menyesuaikan semua peraturan perundang-undangan yang memuat ketentuan tentang segisegi lingkungan hidup yang kini telah berlaku seperti antara lain peraturan perundang-undangan dibidang pengairan, perkebunan dan energi, kehutanan, perlindungan dan pelestarian alam, industri, pemukiman, tata ruang dan tata guna tanah. Semua peraturan perundang-undangan tersebut dapat terangkum dalam satu sistem Hukum Lingkungan Indonesia. Lihat M. Daud Silalahi, Op.cit, hlm. 36.

4 Rony Andre Christian Naldo, 2021, Pertanggungjawaban Mutlak Korporasi Terhadap Kerugian Lingkungan Hidup (Studi Kasus Kebakaran Lahan Perkebunan di Pulau Sumatera), Disertasi, Program Studi Doktor Ilmu Hukum, Fakultas Hukum, Universitas Sumatera Utara, Medan, hlm. 426. Lihat juga Mochtar
} 
Berdasarkan ketentuan Pasal 28 H ayat (1) UUD 1945, Pasal 9 ayat (3) dan Pasal 69 ayat (1) Undang-Undang Nomor 39 Tahun 1999 Tentang Hak Asasi Manusia (UU Nomor 39 Tahun 1999), serta Pasal 65 ayat (1) UU Nomor 32 Tahun 2009, hak atas lingkungan hidup yang baik dan sehat merupakan hak konstitusional dan Hak Asasi Manusia (HAM) bagi setiap Warga Negara Indonesia (WNI). Untuk itu Pemerintah, Pemerintah Daerah (Pemda) dan semua subjek hukum berkewajiban untuk melakukan perlindungan dan pengelolaan lingkungan hidup yang mewujudkan pembangunan berkelanjutan.

Korporasi (yang dimaksud adalah Perseroan Terbatas $\{\mathrm{PT}\}$ ) merupakan subjek hukum. ${ }^{5}$ Hingga saat sekarang ini banyak korporasi yang melakukan aktivitas bisnis perkebunan (kelapa sawit) di Indonesia.

Sesuai dengan ketentuan Pasal 2 Undang-Undang Nomor 40 Tahun 2007 Tentang Perseroan Terbatas (UU Nomor 40 Tahun 2007), aktivitas bisnis yang dilakukan korporasi tidak boleh bertentangan dengan ketentuan peraturan perundang-undangan dan/atau kesusilaan (kepatutan, ketelitian, dan kehati-hatian). Untuk itu berdasarkan ketentuan Pasal 15 huruf a dan b Undang-Undang Nomor 25 Tahun 2007 Tentang Penanaman Modal (UU Nomor 25 Tahun 2007), Pasal 74 ayat (1) UU Nomor 40 Tahun 2007, serta Pasal 3 Peraturan Pemerintah Nomor 47 Tahun 2012 Tentang Tanggung Jawab Sosial dan Lingkungan Perseroan Terbatas (PP Nomor 47 Tahun 2012), dalam melakukan aktivitas bisnisnya korporasi harus melaksanakan kewajiban hukumnya menerapkan Good Corporate Governance (GCG) dan Corporate Social Responsibility (CSR) yang mencakup triple $P$ bottom line (Profit, People, Planet) di dalam maupun di luar lingkungan korporasi, guna terwujudnya pembangunan berkelanjutan. ${ }^{6}$

Terkait dengan kewajiban hukum menerapkan GCG dan CSR, berdasarkan ketentuan Pasal 67 UU Nomor 32 Tahun 2009, dan Pasal 67 ayat (1) Undang-Undang Nomor 39 Tahun 2014 Tentang Perkebunan (UU Nomor 39 Tahun 2014), dalam melakukan aktivitas bisnisnya korporasi berkewajiban memelihara kelestarian fungsi lingkungan hidup serta mengendalikan pencemaran/kerusakan lingkungan hidup. Sehubungan dengan itu, berdasarkan ketentuan Pasal 68 UU Nomor 32 Tahun 2009, dalam melakukan aktivitas bisnisnya korporasi menyandang 3 kewajiban hukum. Pertama, memberikan informasi yang terkait dengan perlindungan dan pengelolaan lingkungan hidup secara benar, akurat, terbuka, dan tepat waktu. Kedua, menjaga keberlanjutan fungsi lingkungan hidup. Ketiga, menaati ketentuan tentang baku mutu lingkungan hidup/kriteria baku kerusakan lingkungan hidup. Selain itu, berdasarkan ketentuan Pasal 69 ayat (1) huruf a UU Nomor 32 Tahun 2009, dan Pasal 32 ayat (1) dan (2) UU Nomor 39 Tahun 2014, dalam melaksanakan aktivitas bisnisnya, korporasi juga dilarang melakukan perbuatan yang menyebabkan pencemaran/kerusakan lingkungan hidup.

Kebakaran lahan perkebunan korporasi dapat menyebabkan terjadinya pencemaran melampaui baku mutu lingkungan hidup (baku mutu udara ambien) daerah maupun nasional,

Kusumaatmadja, 1975, Fungsi dan Perkembangan Hukum Dalam Pembangunan Nasional, Bina Cipta, Bandung, hlm. 11.

${ }^{5}$ Dalam hukum, istilah "person (orang)" mencakup mahluk pribadi, yakni manusia (natuurlijk persoon) dan badan hukum (persona moralis/legal person/legal entity). Ke 2 (dua)nya adalah subjek hukum, sehingga ke 2 (dua)nya adalah penyandang hak dan kewajiban hukum. Lihat Ridwan Khairandy, 2009, Perseroan Terbatas (Doktrin, Peraturan Perundang-undangan, dan Yurisprudensi), Kreasi Total Media, Yogyakarta, hlm. 4.

${ }^{6}$ Pembangunan berkelanjutan dapat diturunkan menjadi 4 (empat) elemen inti. Pertama, asas integrasi (integration principle). Kedua, asas pemanfaatan berkelanjutan (sustainable use). Ketiga, asas keadilan intra generasi (intragenerational equity). Keempat, asas keadilan antar generasi (intergenerational equity). Lihat Andri G. Wibisana, 2017, Keadilan Dalam Satu/Intra Generasi (Sebuah Pengantar Berdasarkan Taksonomi Keadilan Lingkungan), Jurnal Mimbar Hukum, Volume 29, Nomor 2, Fakultas Hukum, Universitas Gadjah Mada, Yogyakarta, hlm. 293. 
yang telah ditentukan dalam Peraturan Menteri Lingkungan Hidup Nomor 12 Tahun 2010 Tentang Pelaksanaan Pengendalian Pencemaran Udara di Daerah (Permen LH Nomor 12 Tahun 2010) dan Peraturan Pemerintah Nomor 41 Tahun 1999 Tentang Pengendalian Pencemaran Udara (PP Nomor 41 Tahun 1999). Selain itu juga dapat menyebabkan terjadinya kerusakan melampaui kriteria baku kerusakan lingkungan hidup, yang telah ditentukan dalam Peraturan Pemerintah Nomor 4 Tahun 2001 Tentang Pengendalian Kerusakan dan/atau Pencemaran Lingkungan Hidup yang Berkaitan Dengan Kebakaran Hutan dan/atau Lahan (PP Nomor 4 Tahun 2001). ${ }^{7}$

Dengan dapat terjadinya pencemaran melampaui baku mutu udara ambien/kerusakan melampaui kriteria baku kerusakan lingkungan hidup sebab kebakaran lahan perkebunan korporasi, yang mengakibatkan ancaman serius (pada akhirnya menimbulkan kerugian lingkungan hidup $)^{8}$, guna menerapkan GCG dan CSR, berdasarkan ketentuan Pasal 69 ayat (1) huruf h UU Nomor 32 Tahun 2009, Pasal 56 ayat (1) UU Nomor 39 Tahun 2014, dan Pasal 11 PP Nomor 4 Tahun 2001, dalam melakukan aktivitas bisnisnya korporasi dilarang membuka/mengolah lahan perkebunan dengan cara membakar. Faktanya, di berbagai wilayah Indonesia telah terjadi kebakaran lahan perkebunan berbagai korporasi (PT. KA, PT. WAJ, PT. SKM, PT. AER, dan lainnya) yang mengakibatkan ancaman serius.

Dikaji berdasarkan Hukum Perdata ${ }^{9}$, kebakaran lahan perkebunan korporasi yang mengakibatkan ancaman serius merupakan PMH. ${ }^{10}$ Berdasarkan ketentuan Pasal 1365 Kitab Undang-Undang Hukum Perdata (KUH Perdata), menimbulkan kewajiban pelaku (korporasi) untuk membayar ganti rugi atas kerugian lingkungan hidup yang terjadi (pertanggungjawaban berdasarkan unsur kesalahan).

Dikaji berdasarkan Hukum Lingkungan ${ }^{11}$, kebakaran lahan perkebunan korporasi yang mengakibatkan ancaman serius juga merupakan PMH. Berdasarkan ketentuan Pasal 88 UU

\footnotetext{
${ }^{7}$ Masalah lingkungan hidup dapat dibedakan menjadi 3 (tiga) kelompok. Pertama, pencemaran lingkungan hidup (pollution). Kedua, penggunaan atau pemanfaatan lahan yang salah (land misuse). Ketiga, pengerukan secara berlebihan yang menyebabkan habisnya SDA (natural resource depletion). Lihat Richard Stewart, and James E. Krier, 1978, Environmental Law and Policy, The Bobbs Merril, Indianapolis, New York, hlm. 3-5.

Dari segi hukum di Indonesia, permasalahan lingkungan hanya dibedakan dalam 2 (dua) hal. Pertama, kerusakan. Kedua, pencemaran. Lihat Laode M. Syarif, dan Andri G. Wibisana, 2010, Hukum Lingkungan (Teori, Legislasi, dan Studi Kasus), Raja Grafindo Persada, Jakarta, hlm. 3.

${ }^{8}$ Pada Pasal 1 angka (2) Peraturan Menteri Lingkungan Hidup Nomor 7 Tahun 2014 Tentang Kerugian Lingkungan Hidup Akibat Pencemaran dan/atau Kerusakan Lingkungan Hidup (Permen LH Nomor 7 Tahun 2014), ditentukan bahwa: "Kerugian lingkungan hidup adalah kerugian yang timbul akibat pencemaran dan/atau kerusakan lingkungan hidup yang bukan merupakan hak milik privat”.

${ }^{9}$ Materi Hukum Lingkungan merupakan bagian dari Hukum Administrasi, dan juga mengandung aspek Hukum Pajak, Hukum Internasional, Hukum Penataan Ruang, Hukum Perdata, Hukum Pidana, serta tidak dapat digolongkan dalam pembidangan hukum klasik. Lihat Siti Sundari Rangkuti, 1996, Hukum Lingkungan dan Kebijaksanaan Lingkungan Nasional, Airlangga University Press, Surabaya, hlm. 3-4.

${ }^{10} \mathrm{PMH}$ merupakan suatu perbuatan atau suatu kealpaan berbuat, yang melanggar hak orang lain atau bertentangan dengan kewajiban hukum pelaku (orang yang melakukan perbuatan) atau melanggar baik kesusilaan, maupun bertentangan dengan keharusan yang harus diindahkan dalam pergaulan masyarakat tentang orang atau barang. Lihat M.A. Moegni Djojodirdjo, 1982, Perbuatan Melawan Hukum, Pradnya Paramita, Jakarta, hlm. 25.

PMH adalah perbuatan yang melanggar hak (subjektif) orang lain atau perbuatan (atau tidak berbuat) yang bertentangan dengan kewajiban hukum berdasarkan peraturan perundang-undangan dan/atau bertentangan dengan hukum tidak tertulis yang seharusnya dilaksanakan orang dalam kehidupan masyarakat dengan mengingat adanya alasan pembenar menurut hukum. Lihat juga Rosa Agustina, 2003, Perbuatan Melawan Hukum, Program Pasca Sarjana, Fakultas Hukum, Universitas Indonesia, Jakarta, hlm. 8.

${ }^{11}$ Hukum Lingkungan berfungsi sebagai instrumen kebijakan pembangunan berkelanjutan. Negara-negara yang telah berperan serta dalam Stockholm Declaration 1972 dan Rio Declaration 1992 masih belum berhasil mentransformasikan asas-asas Hukum Lingkungan Internasional kedalam perilaku nyata warga negaranya khususnya korporasi yang umumnya menjadi sumber terjadinya masalah lingkungan hidup sehingga konsep
} 
Nomor 32 Tahun 2009, menimbulkan pertanggungjawaban mutlak terhadap korporasi untuk membayar ganti rugi atas kerugian lingkungan hidup yang terjadi tanpa perlu pembuktian unsur kesalahan. ${ }^{12}$

\section{B. PEMBAHASAN}

\section{Konsep Pertanggungjawaban Mutlak Sebab Kebakaran Lahan Perkebunan Mengakibatkan Ancaman Serius}

Hukum ${ }^{13}$ menolak hal yang bertentangan dan tidak layak (lex rejicit superflua pugnantia incongrua). ${ }^{14}$ Korporasi (melalui Direksi) berkewajiban hukum menerapkan GCG dan CSR yang merupakan inti dari etika bisnis, guna terwujudnya pembangunan berkelanjutan.

Fakta adanya PMH kebakaran lahan perkebunan berbagai korporasi yang mengakibatkan ancaman serius, ditegaskan bahwa dalam melakukan aktivitas bisnisnya berbagai korporasi tersebut gagal melaksanakan kewajiban hukumnya menerapkan GCG dan CSR. Selain itu juga ditegaskan bahwa korporasi telah melakukan perbuatan yang bertentangan dengan sikap yang baik dalam masyarakat untuk memperhatikan kepentingan orang lain (indruist tegen de zorgvuldigheid/welke in het maatschappelijk verkeer betaamt ten aanzien van anders persoon of goed). ${ }^{15}$

PMH kebakaran lahan perkebunan berbagai korporasi yang mengakibatkan ancaman serius melanggar hak subjektif (hak perorangan) orang lain atas lingkungan hidup yang baik dan sehat, yang dilindungi dan dijamin secara hukum oleh Pemerintah berdasarkan ketentuan Pasal 28 H ayat (1) UUD 1945, Pasal 9 ayat (3) UU Nomor 39 Tahun 1999, dan Pasal 65 ayat

pembangunan berkelanjutan belum sepenuhnya mewujud. Menyadari fakta ini United Nation Environment Programme (UNEP) mendorong negara-negara untuk membangun environmental rule of law sebagai prasyarat tegaknya Hukum Lingkungan. Ciri-ciri environmental rule of law adalah adanya norma-norma Hukum Lingkungan yang adil, jelas, dan dapat dilaksanakan, tersedianya peran serta masyarakat dalam pengambilan keputusan, akses informasi lingkungan hidup bagi masyarakat, adanya peran dan kordinasi yang jelas diantara instansi-instansi Pemerintah, lembaga-lembaga Pemerintah yang berintegritas, adanya interpretasi hukum yang mengutamakan perlindungan lingkungan hidup. Environmental rule of law terkait juga dengan tata kelola pemerintahan yang baik. Ke 2 (dua) konsep ini secara timbal balik saling melengkapi dan saling mendukung. Jika ciri-ciri environmental rule of law dikaitkan dengan sistem hukum Indonesia, beberapa prasyarat normatif sudah dipenuhi, tetapi ada prasyarat-prasyarat lain yang belum mewujud. Untuk itu masih sangat diperlukan upaya dan perhatian terus-menerus dikalangan Ahli hukum pada umumnya dan khususnya Ahli Hukum Lingkungan dan aktivitis lingkungan hidup untuk menyuarakan agar Indonesia menerapkan environmental rule of law secara konsisten. Lihat Takdir Rahmadi, 2015, Hukum Lingkungan, Raja Grafindo Persada, Jakarta, hlm. 211-212.

${ }^{12}$ Ganti rugi dibayarkan korporasi pasca adanya putusan lembaga peradilan yang telah berkekuatan hukum tetap dan pasti (in kracht van gewijsde) atas gugatan PMH yang dapat diajukan oleh Pemerintah, Pemda, dan masyarakat (secara perorangan maupun berkelompok). Khusus bagi organisasi lingkungan hidup, gugatan PMH yang diajukan terhadap korporasi hanya terbatas pada tuntutan untuk melakukan tindakan tertentu tanpa adanya tuntutan ganti rugi, kecuali biaya, atau pengeluaran riil. Lihat Rony Andre Christian Naldo, Op.cit, hlm. 10-11.

${ }^{13}$ Law is a political product established by the Government to regulate the life of the people, by its very nature of governing and forcing. With the law, it is expected to create justice, legal certainty, the benefit/happiness, truth, peace, order, and prosperity in people's lives (Hukum merupakan suatu produk politik yang dibentuk Pemerintah untuk mengatur kehidupan masyarakat, dengan sifatnya yakni mengatur dan memaksa. Dengan adanya hukum, diharapkan dapat tercipta keadilan, kepastian hukum, kemanfaatan/kebahagiaan, kebenaran, kedamaian, ketertiban, dan kesejahteraan dalam kehidupan masyarakat). Lihat Rony Andre Christian Naldo, and Ningrum Natasya Sirait, 2017, Implementation of Corporate Absolute Responsibility for Land Fires Causing Air Pollution, Advances in Social Science, Education and Humanities Research, Volume 141, International Conference on Public Policy Social Computing and Development, Medan, hlm. 57.

${ }^{14}$ Rony Andre Christian Naldo, Pertanggungjawaban ......, Op.cit, hlm. 463.

${ }^{15}$ Lihat juga Munir Fuady, 2005, Perbuatan Melawan Hukum (Pendekatan Kontemporer), Citra Aditya Bakti, Bandung, hlm. 11. 
(1) UU Nomor 32 Tahun 2009. Sesuai dengan pendapat Shidarta, melanggar hak subjektif orang lain diartikan secara luas. Orang lain tersebut tidak hanya subjek yang berdomisili di lokasi yang terkena dampak secara langsung, akan tetapi juga subjek yang dirugikan secara idealisme. $^{16}$

Konsekuensi hukum PMH tersebut berupa pertanggungjawaban terhadap korporasi untuk membayar ganti rugi atas kerugian lingkungan hidup yang terjadi. Hans Kelsen dalam Teori Tanggung Jawab Hukum, menegaskan bahwa:

"That a person is legally responsible for certain behavior or that he bears the legal responsibility therefor means that he is liable to a sanction in case of contrary behavior. Normally, that is, in case the sanctions is directed against the immediate delinquent, it is his own behavior for which an individual is responsible. In this case the subject of the legal responsibility and the subject of the legal duty coincide (Bahwa orang bertanggung jawab secara hukum atas suatu perbuatan tertentu atau bahwa orang tersebut memikul tanggung jawab hukum karena itu berarti bahwa ia dapat dikenakan sanksi jika terjadi perbuatan yang bertentangan. Umumnya, jika sanksi didasarkan terhadap perbuatan seseorang, maka perbuatannya dipertanggungjawabkan. Dalam hal ini subjek tanggung jawab hukum dan subjek kewajiban hukum itu adalah sama)". ${ }^{17}$

\section{${ }^{16}$ Rony Andre Christian Naldo, Pertanggungjawaban ......, Op.cit, hlm. 190.}

PMH kebakaran lahan perkebunan berbagai korporasi yang mengakibatkan ancaman serius bertentangan dengan kewajiban hukum korporasi yang telah ditentukan dalam berbagai peraturan perundang-undangan. Kewajiban hukum korporasi yang dimaksud adalah Pasal 28 J ayat (1) UUD 1945, Pasal 69 ayat (1) UU Nomor 39 Tahun 1999, Pasal 15 huruf a, b dan e UU Nomor 25 Tahun 2007, Pasal 74 ayat (1) UU Nomor 40 Tahun 2007, Pasal 67, Pasal 68 huruf b, c, UU Nomor 32 Tahun 2009, Pasal 32 ayat (1) dan (2), Pasal 67 ayat (1) UU Nomor 39 Tahun 2014, Pasal 12, Pasal 13, dan Pasal 14 ayat (1) PP Nomor 4 Tahun 2001, Pasal 3 PP Nomor 47 Tahun 2012, serta Pasal 3 ayat (1) Peraturan Menteri Lingkungan Hidup Nomor 10 Tahun 2010 Tentang Mekanisme Pencegahan Pencemaran dan/atau Kerusakan Lingkungan Hidup yang Berkaitan Dengan Kebakaran Hutan dan/atau Lahan (Permen LH Nomor 10 Tahun 2010). PMH kebakaran lahan perkebunan berbagai korporasi yang mengakibatkan ancaman serius (yang bertentangan dengan kewajiban hukum) merupakan pelanggaran asas yang ditentukan pada Pasal 3 ayat (1) huruf a, g, h UU Nomor 25 Tahun 2007 (asas kepastian hukum, asas keberlanjutan, asas berwawasan lingkungan), Pasal 2 huruf b, c, e, f UU Nomor 32 Tahun 2009 (asas kelestarian dan keberlanjutan, asas keserasian dan keseimbangan, asas manfaat, asas kehati-hatian), dan Pasal 2 huruf d, j UU Nomor 39 Tahun 2014 (asas keberlanjutan, asas kelestarian fungsi lingkungan hidup). Dengan adanya pelanggaran asas, PMH kebakaran lahan perkebunan berbagai korporasi yang mengakibatkan ancaman serius secara atribusi juga melanggar ketentuan Pasal 16 huruf d, f UU Nomor 25 Tahun 2007, Pasal 2 UU Nomor 40 Tahun 2007, Pasal 69 ayat (1) huruf a, h UU Nomor 32 Tahun 2009, Pasal 56 ayat (1) UU Nomor 39 Tahun 2014, dan Pasal 11 PP Nomor 4 Tahun 2001. PMH kebakaran lahan perkebunan berbagai korporasi yang mengakibatkan ancaman serius juga bertentangan dengan kesusilaan. Ditegaskan bertentangan dengan kesusilaan karena PMH kebakaran lahan perkebunan berbagai korporasi yang mengakibatkan ancaman serius bukanlah perbuatan yang baik, sebab hanya memberikan keuntungan bagi korporasi, dan merugikan lingkungan hidup.

17 Hans Kelsen, 1949, General Theory of Law and State, Harvard University Press, Cambridge Massachusetts, hlm. 65.

Secara umum tanggung jawab hukum dapat diartikan sebagai suatu konsekuensi hukum yang timbul sebab adanya suatu kesalahan (kesengajaan ataupun kelalaian) maupun tanpa adanya suatu kesalahan. Umumnya konsep tanggung jawab hukum akan merujuk kepada tanggung jawab dalam bidang Hukum Privat (tanggung jawab perdata), dan tanggung jawab dalam bidang Hukum Publik (misalnya tanggung jawab pidana maupun administrasi). Berdasarkan perikatan ada 2 (dua) jenis tanggung jawab dalam Hukum Perdata. Pertama, tanggung jawab hukum karena persetujuan/hubungan kontraktual. Kedua, tanggung jawab hukum karena undang-undang. Berdasarkan Hukum Perdata, dasar pertanggungjawaban dibagi menjadi 2 (dua) jenis. Pertama, pertanggungjawaban berdasarkan unsur kesalahan (kesengajaan maupun kelalaian). Kedua, pertanggungjawaban tanpa perlu pembuktian unsur kesalahan. Ditegaskan bahwa ada konsep pertanggungjawaban berdasarkan unsur kesalahan dan ada konsep pertanggungjawaban tanpa perlu pembuktian unsur kesalahan, yang dikenal dengan istilah "pertanggungjawaban mutlak". Lihat Rony Andre Christian Naldo, Pertanggungjawaban ......, Op.cit, hlm. 28-29. 
Sesuai dengan ketentuan Pasal 88 UU Nomor 32 Tahun 2009, pertanggungjawaban yang dimaksud adalah pertanggungjawaban mutlak. Konsep pertanggungjawaban mutlak berawal dari perkara Rylands vs. Fletcher di Inggris pada tahun 1868, yang kemudian ditransplantasi dalam peraturan perundang-undangan berbagai negara dan dalam berbagai konvensi internasional. $^{18}$

Dikaji dari peraturan perundang-undangan terkait, konsep pertanggungjawaban mutlak sebab kebakaran lahan perkebunan mengakibatkan ancaman serius mencakup 13 (tiga belas) klausul hukum. Pertama, sengketa diselesaikan secara non litigasi atau litigasi, yang dipilih secara sukarela oleh para pihak. Gugatan PMH hanya dapat diajukan apabila penyelesaian sengketa secara non litigasi dinyatakan tidak berhasil oleh salah satu atau para pihak yang bersengketa (Pasal 84 UU Nomor 32 Tahun 2009). Kedua, penyelesaian sengketa secara non litigasi dilakukan untuk mencapai kesepakatan mengenai bentuk dan besarnya ganti rugi, tindakan pemulihan akibat ancaman serius, tindakan tertentu untuk menjamin tidak akan terulangnya ancaman serius, dan tindakan untuk mencegah timbulnya dampak negatif terhadap lingkungan hidup. Dapat digunakan jasa Mediator dan/atau Arbiter untuk membantu menyelesaikan sengketa (Pasal 85 ayat $\{1\}$ dan $\{3\}$ UU Nomor 32 Tahun 2009). Ketiga, pelaku wajib membayar ganti rugi atas kerugian lingkungan hidup sebagai realisasi asas ${ }^{19}$ yang telah ditentukan pada Pasal 2 huruf j UU Nomor 32 Tahun 2009 (asas pencemar membayar) dan/atau melakukan tindakan hukum tertentu, restrukturisasi ${ }^{20}$ tidak menghapus pertanggungjawaban, dan lembaga peradilan dapat menetapkan pembayaran uang paksa yang diputuskan berdasarkan peraturan perundang-undangan atas setiap hari keterlambatan pelaksanaan perintah lembaga peradilan untuk melakukan tindakan hukum tertentu demi pelestarian fungsi lingkungan hidup (Pasal 87 UU Nomor 32 Tahun 2009). Keempat, pelaku bertanggung jawab mutlak atas kerugian lingkungan hidup yang terjadi tanpa perlu pembuktian unsur kesalahan oleh penggugat sebagai dasar pembayaran ganti rugi. Hal ini merupakan lex specialist dari gugatan PMH pada umumnya. ${ }^{21}$ Besarnya nilai ganti rugi dapat

${ }^{18}$ Laode M. Syarif, dan Andri G. Wibisana, Op.cit, hlm. 583.

Strict liability merupakan dasar pertanggungjawaban perdata yang menurut mayoritas Ahli hukum, berasal dari Inggris. Dalam hal ini para Ahli hukum biasanya merujuk pada Putusan Rylands vs. Fletcher (1868). Dalam perkara ini para tergugat adalah pemilik tempat penggilingan/kincir air/mill. Setelah memperoleh persetujuan dari pemilik tanah yang bertetangga dengannya, tergugat membuat kolam penampungan air (reservoir) untuk menyuplai air bagi kincir. Guna membuat reservoir ini, tergugat mempekerjakan Insinyur dan kontraktor bangunan yang kompeten. Tergugat sendiri tidak terlibat dalam pengerjaan pembuatan reservoir tersebut. Tanpa diketahui oleh tergugat, diantara reservoir dan tanah pertambangan penggugat ternyata terhubung oleh terowongan (shafts) bekas pertambangan yang telah tidak terpakai lagi. Ketika reservoir tersebut diisi oleh air, maka air tersebut kemudian masuk ke dalam terowongan, dan pada akhirnya air tersebut membanjiri tanah pertambangan dari penggugat. Lihat Francis H. Bohlen, 1911, The Rule in Rylands v. Fletcher Part I, University of Pennsylvania Law Review and American Law Register, Volume 59, Philadelphia, hlm. 298-299.

${ }^{19}$ In law, there are an essential and basic elements, namely the principle. The principle is the ratio legitimate of various laws (Dalam peraturan hukum terdapat suatu unsur yang penting dan pokok, yaitu asas. Asas merupakan ratio legis dari berbagai peraturan hukum). Lihat Rony Andre Christian Naldo, and Ningrum Natasya Sirait, Implementation ......, Op.cit, hlm. 60.

${ }^{20}$ Restrukturisasi usaha adalah melakukan penataan terhadap nilai seluruh mata rantai bisnis korporasi dengan tujuan terciptanya daya saing dan kompetisi. Ada 7 (tujuh) cara yang dapat dilakukan. Pertama, merger dan akuisisi. Kedua, mengatur kembali korporasi holding dan konsolidasi (regrouping holding and consolidation). Ketiga, kerja sama manajemen atau operasional (joint management or operation). Keempat, kerja sama strategis. Kelima, mengurangi beberapa usahanya, atau produk, atau cabang korporasi. Keenam, memecah korporasi menjadi beberapa korporasi. Ketujuh, likuidasi. Lihat Ridwan Khairandy, Op.cit, hlm. 280.

${ }^{21}$ Berdasarkan ketentuan Pasal 1365 KUH Perdata, suatu perbuatan dapat dikategorikan sebagai PMH apabila memenuhi 5 (lima) unsur. Pertama, perbuatan. Kedua, perbuatan tersebut melawan hukum. Ketiga, ada 
ditetapkan sampai batas waktu tertentu, dalam arti jika menurut penetapan peraturan perundang-undangan ditentukan keharusan asuransi terhadap aktivitas bisnis pelaku atau telah tersedia dana lingkungan hidup (Pasal 88 UU Nomor 32 Tahun 2009). Kelima, dalam penyelesaian sengketa secara litigasi, sesuai dengan ketentuan Pasal 1967 KUH Perdata daluarsa pengajuan gugatan PMH adalah 30 (tiga puluh) tahun sejak diketahui terjadinya PMH (Pasal 89 ayat \{1\} UU Nomor 32 Tahun 2009). Keenam, gugatan PMH dapat diajukan Pemerintah melalui Kementerian Lingkungan Hidup dan Kehutanan (KLHK), Pemda melalui instansi yang bertanggung jawab dibidang lingkungan hidup, masyarakat (perseorangan ataupun berkelompok), maupun organisasi lingkungan hidup (Pasal 90 ayat \{1\}, Pasal 91 ayat $\{1\}$, dan Pasal 92 ayat $\{1\}$ UU Nomor 32 Tahun 2009). Ketujuh, tidak ada klausul hukum pembatasan pertanggungjawaban mutlak perihal alasan pemaaf. Kedelapan, kerugian berupa kerugian lingkungan hidup, yakni kerugian yang timbul akibat ancaman serius, yang bukan merupakan hak milik privat (Penjelasan Pasal 90 ayat \{1\} UU Nomor 32 Tahun 2009 dan Pasal 1 angka \{2\} Permen LH Nomor 7 Tahun 2014). Kesembilan, kerugian lingkungan hidup meliputi kerugian karena dilampauinya baku mutu lingkungan hidup, penggantian biaya pelaksanaan penyelesaian sengketa, penggantian biaya penanggulangan ancaman serius dan pemulihan fungsi lingkungan hidup, serta kerugian ekosistem (Pasal 3 Permen LH Nomor 7 Tahun 2014). Kesepuluh, penghitungan kerugian lingkungan hidup dilakukan oleh Ahli dibidang pencemaran/kerusakan dan/atau valuasi ekonomi lingkungan hidup, yang berdasarkan Surat Keputusan Ketua Mahkamah Agung Nomor 36/KMA/SK/II/2013 Tentang Pemberlakuan Pedoman Penanganan Perkara Lingkungan Hidup (SK KMA Nomor 36/KMA/SK/II/2013) dapat dijadikan sebagai parameter menghitung besarnya kerugian lingkungan hidup (Pasal 4 ayat $\{1\}$ Permen LH Nomor 7 Tahun 2014). Kesebelas, penghitungan kerugian lingkungan hidup oleh Ahli dipergunakan sebagai penilaian awal dalam penyelesaian sengketa secara non litigasi maupun litigasi, yang dapat mengalami perubahan akibat pengaruh faktor non teknis dan teknis (Pasal 6 Permen LH Nomor 7 Tahun 2014). Keduabelas, dalam penyelesaian sengketa secara non litigasi, besarnya kerugian lingkungan hidup ditentukan berdasarkan kesepakatan para pihak yang bersengketa, sedangkan dalam penyelesaian sengketa secara litigasi besarnya kerugian lingkungan hidup ditentukan berdasarkan putusan lembaga peradilan yang telah berkekuatan hukum tetap dan pasti (Pasal 7 Permen LH Nomor 7 Tahun 2014). Ketigabelas, pembayaran kerugian lingkungan hidup merupakan penerimaan negara bukan pajak yang wajib disetor ke kas negara (Pasal 8 Permen LH Nomor 7 Tahun 2014).

\section{Kelemahan Konsep Pertanggungjawaban Mutlak Sebab Kebakaran Lahan Perkebunan Mengakibatkan Ancaman Serius}

Pertanggungjawaban mutlak merupakan konsep yang diadopsi Indonesia dari perkembangan tort pada negara Common Law yang terjadi pasca perkembangan masyarakat agraris ke masyarakat industri. Dalam Ilmu Hukum, pengadopsian konsep pertanggungjawaban mutlak dari Common Law tersebut ke Indonesia (yang identik Civil

kesalahan. Keempat, ada kerugian. Kelima, terdapat hubungan kausal antara perbuatan dengan kerugian. Lihat Rony Andre Christian Naldo, Pertanggungjawaban ......, Op.cit, hlm. 64.

Di Indonesia, untuk mengatakan bahwa orang telah melakukan PMH, merujuk pada Pasal 1365 KUH Perdata, perbuatan orang tersebut harus memenuhi 5 (lima) unsur. Pertama, sifat melanggar hukumnya suatu perbuatan (onrechtmatigheid). Kedua, kesalahan. Ketiga, kerugian (schade). Keempat, hubungan sebab akibat (causal verband). Kelima, relativiteit. Lihat Paulus Effendi Lotulung, 1993, Penegakan Hukum Lingkungan Oleh Hakim Perdata, Citra Aditya Bakti, Bandung, hlm. 31. 
Law) dikenal dengan istilah "pencangkokan hukum/transplantasi hukum (legal adoption/legal borrowing/legal reception/legal transplantation/legal transplants)". ${ }^{22}$

Transplantasi hukum dapat diartikan sebagai pencangkokan hukum dari suatu negara oleh negara lain, yang berbeda fakta sosial dan sistem hukumnya. Menurut Alan Watson, transplantasi hukum merupakan the borrowing and transmissibility of rules from one society or system to another (meminjam atau mentrasmisikan aturan hukum dari suatu masyarakat atau sistem ke yang lain). ${ }^{23}$ Alan Watson, menggunakan istilah "legal transplants" ${ }^{24}$ untuk menegaskan suatu proses mengadopsi atau mentransmisikan aturan hukum dari suatu negara ke tempat negara lain, yang kemudian di negara yang mengadopsi aturan itu menerapkan bersama-sama dengan aturan hukum yang sudah ada sebelumnya.

Transplantasi hukum sering dilakukan pada pembuatan undang-undang. Pemerintah bersama Dewan Perwakilan Rakyat (DPR) mempunyai 2 (dua) opsi dalam membuat aturan undang-undang. Pertama, mengadopsi aturan hukum yang telah ada dan berlaku di negara lain yang menganut sistem hukum yang berbeda. Kedua, melakukan sendiri proses pencarian aturan hukum yang sesuai dengan identitas bangsa dan negara, yang sejalan dengan tradisi, budaya dan sejarah. ${ }^{25}$

Ada 4 (empat) faktor yang dapat membuat ataupun mempengaruhi masuknya aturanaturan hukum yang ditransplantasi dari suatu negara pada suatu negara. Pertama, transplantasi dapat dilakukan dengan mudah, dan cepat. Kedua, para Ahli hukum yang cenderung mencontoh aturan hukum yang dianggap baik dan benar. Ketiga, kolonialisme. Keempat, globalisasi. ${ }^{26}$ Faktor yang mempengaruhi transplantasi konsep pertanggungjawaban mutlak di Indonesia adalah globalisasi. ${ }^{27}$

Dalam tort pada Common Law, pertanggungjawaban mutlak dibebankan kepada orang yang menyebabkan kerugian. Maksud tidaklah menjadi penting, unsur utama dalam rumus tort pada permulaannya adalah sebab. Dengan demikian, orang dipertanggungjawabkan terhadap kerugian yang timbul tanpa perlu pembuktian unsur kesalahan. Untuk itu, maka tidak perlu diperhatikan perbuatan orang tersebut merupakan unsur kesengajaan ataupun unsur kelalaian.

Menurut L.B. Curson, konsep pertanggungjawaban mutlak didasarkan pada 3 (tiga) alasan. Pertama, adalah sangat esensial untuk menjamin dipatuhinya peraturan penting tertentu yang diperlukan untuk kesejahteraan sosial. Kedua, pembuktian adanya mens rea akan menjadi sangat sulit untuk pelanggaran yang berhubungan dengan kesejahteraan sosial itu. Ketiga, tingginya tingkat bahaya sosial yang ditimbulkan oleh perbuatan yang bersangkutan. $^{28}$

${ }^{22}$ Rony Andre Christian Naldo, Pertanggungjawaban ......, Op.cit, hlm. 212-213.

${ }_{23}$ Tri Budiyono, 2009, Transplantasi Hukum, Harmonisasi, dan Potensi (Studi Transplantasi Doktrin yang Dikembangkan Dari Tradisi Common Law Pada Undang-Undang Perseroan Terbatas), Griya Media, Salatiga, hlm. 9.

${ }^{24}$ Lihat Alan Watson, 1993, Legal Transplants (An Approach to Comparative Law), University of Georgia Press, Athens, hlm 21.

${ }^{25}$ Rony Andre Christian Naldo, Pertanggungjawaban ......, Op.cit, hlm. 215.

${ }^{26}$ Ibid.

${ }^{27}$ Indonesia sudah mendukung kesepakatan lingkungan global sejak awal, yang dimulai dari Stockholm Declaration 1972. Indonesia mulai menyusun aturan mengenai lingkungan hidup sejak tahun 1982, yang ditegaskan dengan adanya Undang-undang Nomor 4 Tahun 1982 Tentang Ketentuan-ketentuan Pokok Pengelolaan Lingkungan Hidup (UU Nomor 4 Tahun 1982). Lihat juga bagian Menimbang huruf e UU Nomor 32 Tahun 2009, yang mempertimbangkan: "Bahwa pemanasan global yang semakin meningkat mengakibatkan perubahan iklim sehingga memperparah penurunan kualitas lingkungan hidup karena itu perlu dilakukan perlindungan dan pengelolaan lingkungan hidup".

${ }^{28}$ Lihat juga Muladi, dan Dwidja Priyatno, 2011, Pertanggungjawaban Pidana Korporasi, Kencana Prenada Media Group, Jakarta, hlm. 107-108. 
Konsep pertanggungjawaban mutlak berkembang dalam praktik untuk mengatasi keterbatasan konsep pertanggungjawaban berdasarkan unsur kesalahan. ${ }^{29}$ Konsep pertanggungjawaban berdasarkan unsur kesalahan membebankan pembuktian kepada penggugat, sehingga sering kali penggugat mengalami kesulitan untuk membuktikan adanya PMH. Konsep ini berawal dari perkara Rylands vs. Fletcher di Inggris pada tahun $1868 .^{30}$

Di Amerika Serikat, pada awalnya konsep pertanggungjawaban mutlak mendapat penolakan. Hakim tetap menuntut adanya pembuktian unsur kesalahan sebagai dasar pertanggungjawaban. ${ }^{31}$ Seiring perkembangan, konsep tersebut diterima di Amerika Serikat sebagai hukum yang akan diberlakukan pada aktivitas yang dianggap sebagai aktivitas yang berbahaya. ${ }^{32}$

Perkembangan konsep pertanggungjawaban mutlak di Amerika Serikat terjadi pada 2 (dua) arah. Pertama, pengadopsian konsep pertanggungjawaban mutlak melalui pengadilan. Kedua, pengadopsian konsep pertanggungjawaban mutlak melalui peraturan perundangundangan. Pengadopsian konsep pertanggungjawaban mutlak melalui peraturan perundangundangan juga memiliki 3 (tiga) ciri lain. Pertama, kanalisasi pertanggungjawaban (chanelling of liability). ${ }^{33}$ Kedua, pembatasan pertanggungjawaban/ganti rugi (financial caps/ceiling). Ketiga, jaminan keuangan (financial responsibility) dan sistem pendanaan lingkungan (environmental fund). ${ }^{34}$

Konsep pertanggungjawaban mutlak sebab kebakaran lahan perkebunan mengakibatkan ancaman serius yang mencakup 13 (tiga belas) klausul hukum, dikaji lebih lanjut berdasarkan konsep pertanggungjawaban mutlak pada Common Law (khususnya Inggris dan Amerika Serikat), dapat ditegaskan bahwa konsep pertanggungjawaban mutlak belum diterapkan sesuai dengan penerapan pada Common Law. Hal tersebut ditegaskan karena konsep pertanggungjawaban mutlak tidak diikuti dengan klausul hukum pembatasan perihal alasan pemaaf, maupun ganti rugi.

Pada Common Law (Inggris), berdasarkan perkara Rylands vs. Fletcher, konsep pertanggungjawaban mutlak diikuti 3 (tiga) klausul hukum pembatasan perihal alasan pemaaf. Pertama, kesalahan penggugat sendiri. Kedua, daya paksa. Ketiga, bencana alam. Dalam UU Nomor 32 Tahun 2009, tidak ada satupun pasal yang mengatur mengenai klausul hukum pembatasan pertanggungjawaban mutlak perihal alasan pemaaf. Fakta tersebut, berbeda dengan ketentuan dalam undang-undang terdahulunya (Undang-Undang Nmor

${ }^{29}$ Lihat juga Syahrul Machmud, 2012, Penegakan Hukum Lingkungan Indonesia (Penegakan Berdasarkan Hukum Administrasi, Hukum Perdata dan Hukum Pidana Menurut Undang-undang Nomor 32 Tahun 2009, Graha Ilmu, Medan, hlm. 209.

${ }^{30}$ Dasar dari pertanggungjawaban bukan lagi perbuatannya memenuhi atau tidak memenuhi kesalahan, tetapi mengenai telah terlibat dalam suatu aktivitas berbahaya yang dapat menimbulkan kerugian. Dalam hal ini, karena telah terlibat dalam aktivitas yang berbahaya, maka bertanggung jawab atas kerugian yang timbul karena bahaya tersebut, tanpa melihat mengenai melawan hukum atau tidaknya aktivitas tersebut. Lihat Laode M. Syarif, dan Andri G. Wibisana, Op.cit, hlm. 51.

${ }^{31}$ Konsep pertanggungjawaban mutlak yang diadopsi dari perkara Rylands vs. Fletcher dianggap sebagai serangan atau ancaman terhadap konsep pertanggungjawaban berdasarkan unsur kesalahan, yang merupakan konsep umum dari pertanggungjawaban berdasarkan Hukum Perdata. Lihat juga Harry H. Ognall, 1958, Some Facets of Strict Tortious Liability In The United States and Their Implications, Notre Dame Lawyer, Volume 33, Issue 2, Indiana, hlm. 242-243.

${ }^{32}$ Lihat juga Cornelius J. Peck, 1971, Negligence and Liability Without Fault in Tort Law, Washington Law Review, Volume 46, Issue 2, Washington, hlm. 237-238.

33 Kanalisasi pertanggungjawaban terjadi ketika undang-undang mengidentifikasi pihak tertentu, dan kemudian menentukan bahwa pihak tersebut secara eksklusif akan bertanggung jawab atas kerugian yang terjadi. Lihat juga Liu Jing, 2013, Compensating Ecological Damage (Comparative and Economic Observations), Intersentia, Cambridge, hlm. 65.

${ }^{34}$ Andri G. Wibisana, 2017, Penegakan Hukum Lingkungan (Melalui Pertanggungjawaban Perdata), Badan Penerbit Fakultas Hukum, Universitas Indonesia, Depok, hlm. 88. 
23Tahun 1997 Tentang Pengelolaan Lingkungan Hidup \{UU Nomor 23 Tahun 1997\}), yang berdasarkan ketentuan Pasal 35 ayat (2) telah menentukan 3 (tiga) klausul hukum pembatasan pertanggungjawaban mutlak perihal alasan pemaaf. Pertama, adanya bencana alam atau peperangan. Kedua, adanya keadaan terpaksa diluar kemampuan manusia. Ketiga, adanya tindakan pihak ketiga. ${ }^{35}$

Sesuai dengan pendapat Morton J. Horwitz, standar asli dari tangggung jawab PMH bukanlah kesalahan tetapi pertanggungjawaban mutlak. Sesuai dengan pendapat Michael Faure, sebenarnya pembatasan pertanggungjawaban mutlak akan mengganggu efektivitas konsep pertanggungjawaban mutlak untuk mendorong kehati-hatian. Dalam hal ini adalah kehati-hatian dalam melakukan aktivitas bisnis, dalam arti bahwa pelaku merealisasikan khususnya asas kehati-hatian yang telah ditentukan pada Pasal 2 huruf f UU Nomor 32 Tahun $2009 .{ }^{36}$

Meskipun demikian, akan tetapi jika dikaji dari asalnya pada Common Law (Inggris), konsep pertanggungjawaban mutlak diikuti klausul hukum pembatasan pertanggungjawaban mutlak perihal alasan pemaaf. Untuk itu maka diharapkan agar pada masa yang akan datang, dalam hal pembaharuan hukum, Pemerintah bersama DPR memperbaharui UU Nomor 32 Tahun 2009, dengan menambahkan klausul hukum perihal alasan pemaaf yang menjadi pembatasan pertanggungjawaban mutlak, yakni karena keadaan kahar (force majeure) berupa bencana alam dan/atau peperangan yang menyebabkan pelaku circumstances (berada dalam keadaan ketidakmungkinan absolut/impossibilitas absolut). ${ }^{37}$

Pada Common Law (Amerika Serikat), konsep pertanggungjawaban mutlak diikuti dengan klausul hukum pembatasan perihal ganti rugi. Hal ini berbeda dengan konsep pertanggungjawaban mutlak di Indonesia, yang tidak diikuti dengan klausul hukum pembatasan perihal ganti rugi. Di Indonesia, berdasarkan ketentuan Pasal 4 ayat (1) Permen LH Nomor 7 Tahun 2014, ganti rugi didasarkan pada hasil perhitungan yang dilakukan oleh Ahli dibidang pencemaran/kerusakan dan/atau valuasi ekonomi lingkungan hidup, yang berdasarkan SK KMA Nomor 36/KMA/SK/II/2013 dapat dijadikan sebagai parameter bagi Hakim untuk menghitung besarnya kerugian lingkungan hidup. ${ }^{38}$

Dengan tidak adanya klausul hukum pembatasan perihal ganti rugi, maka dalam praktik penentuan besarnya ganti rugi, dapat menjadi berdasarkan pada kebijaksanaan Hakim sesuai dengan keadilan dan kepatutan. Hal tersebut tentunya selain dapat menimbulkan ketidakpastian hukum, dapat juga menimbulkan subjektifitas Hakim dalam menentukan besarnya jumlah ganti rugi atas kerugian lingkungan hidup yang harus dibayarkan pelaku.

Untuk itu juga maka diharapkan agar pada masa yang akan datang, dalam hal pembaharuan hukum, Pemerintah bersama DPR memperbaharui UU Nomor 32 Tahun 2009, dengan menambahkan klausul hukum mengenai pembatasan perihal ganti rugi. Dengan demikian pembaharuan hukum yang dilakukan akan mengakomodir kesamaan yang adil, yang oleh John Borden Rawls disebut "justice as fairness". 39

Selain transplantasi konsep pertanggungjawaban mutlak yang tidak sesuai dengan asalnya, perlu juga dikaji mengenai 2 (dua) hal. Pertama, klausul hukum terhadap pelaku yang tidak

\footnotetext{
${ }^{35}$ Rony Andre Christian Naldo, Pertanggungjawaban ......, Op.Cit, hlm. 226.

${ }^{36}$ Ibid. hlm. 227.

${ }^{37}$ Ibid.

${ }^{38}$ Ibid, hlm. 228.

${ }^{39}$ Ibid.

Menurut John Borden Rawls, keadilan adalah kebajikan utama dari hadirnya institusi-institusi sosial. Kebaikan bagi seluruh masyarakat tidak dapat mengesampingkan atau mengganggu rasa keadilan dari setiap orang yang telah memperoleh rasa keadilan, khususnya masyarakat lemah. Lihat Pan Mohamad Faiz, 2009, Teori Keadilan John Rawls (John Rawls' Theory of Justice), Jurnal Konstitusi, Volume 6, Nomor 1, Mahkamah Konstitusi, Jakarta, hlm. 140.
} 
sanggup membayar ganti rugi. Kedua, klausul hukum terhadap pelaku yang tidak patuh putusan lembaga peradilan.

Mengenai klausul hukum terhadap pelaku yang tidak sanggup membayar ganti rugi, dalam UU Nomor 32 Tahun 2009 belum ada ditentukan. Untuk itu maka diharapkan agar pada masa yang akan datang, dalam hal pembaharuan hukum, Pemerintah bersama DPR memperbaharui UU Nomor 32 Tahun 2009, dengan menambahkan klausul hukum mengenai pelaku yang tidak sanggup membayar ganti rugi. Misalnya, pelaku dapat melakukan pembayaran secara berangsur ke kas negara atas sisa ganti rugi yang belum dibayarkan, yang dilakukan berdasarkan perjanjian tertulis. ${ }^{40}$

Mengenai klausul hukum terhadap pelaku yang tidak patuh putusan lembaga peradilan, dalam UU Nomor 32 Tahun 2009 dan Undang-Undang Nomor 48 Tahun 2009 Tentang Kekuasaan Kehakiman (UU Nomor 48 Tahun 2009) belum ada ditentukan. Untuk itu maka diharapkan agar pada masa yang akan datang, dalam hal pembaharuan hukum, Pemerintah bersama DPR memperbaharui UU Nomor 32 Tahun 2009 dan UU Nomor 48 Tahun 2009, dengan menambahkan klausul hukum berupa sanksi pidana terhadap pelaku yang tidak patuh putusan lembaga peradilan tanpa menghapuskan pertanggungjawaban perdata. ${ }^{41}$ Dengan demikian pembaharuan hukum yang dilakukan akan dapat menumbuhkan kepatuhan hukum orang terhadap putusan lembaga peradilan (perdata).

Berdasarkan pemaparan yang telah ada ditegaskan bahwa ada 4 (empat) kelemahan konsep pertanggungjawaban mutlak sebab kebakaran lahan perkebunan mengakibatkan ancaman serius. Pertama, konsep pertanggungjawaban mutlak tidak diikuti dengan klausul hukum pembatasan perihal alasan pemaaf. Kedua, konsep pertanggungjawaban mutlak tidak diikuti dengan klausul hukum pembatasan perihal ganti rugi. Ketiga, belum ada klausul hukum mengenai pelaku yang tidak sanggup membayar ganti rugi. Keempat, belum ada klausul hukum berupa sanksi pidana tanpa menghapuskan pertanggungjawaban perdata terhadap pelaku yang tidak patuh putusan lembaga peradilan.

\section{KESIMPULAN}

Konsep pertanggungjawaban mutlak sebab kebakaran lahan perkebunan mengakibatkan ancaman serius mencakup 13 (tiga belas) klausul hukum, yang masih mempunyai 4 (empat) hal kelemahan. Perlu segera dilakukan pembaharuan hukum terkait 4 (empat) hal kelemahan tersebut guna tercapainya tujuan hukum.

\footnotetext{
${ }^{40}$ Cara melakukan pembayaran secara berangsur ke kas negara atas sisa ganti rugi yang belum dibayarkan tentunya harus dilakukan berdasarkan perjanjian tertulis. Perjanjian tertulis yang dimaksud adalah perjanjian tertulis yang dibuat dan disepakati antara pelaku dengan penggugat. Lebih lanjut, berdasarkan ketentuan Pasal 1338 KUH Perdata, perjanjian tertulis yang dibuat tersebut (yang telah memenuhi syarat sah perjanjian sebagaimana ditentukan pada Pasal 1320 KUH Perdata) berlaku sebagai undang-undang bagi para pihak (pacta sunt servanda). Cara ini tentunya lebih efektif dan efisien apabila dibandingkan melalui cara kepailitan. Lihat Rony Andre Christian Naldo, Pertanggungjawaban ......, Op.cit, hlm. 230.

${ }^{41}$ Pada umumnya dalam perkara perdata, pihak yang kalah tidak patuh terhadap putusan lembaga peradilan (sukarela melaksanakan putusan). Dengan demikian maka pihak yang menang dalam perkara perdata yang telah berkekuatan hukum tetap dan pasti, mengajukan permohonan eksekusi kepada Ketua Pengadilan Negeri, yang eksekusi tersebut akan dilaksanakan oleh Panitera dan Juru Sita dibawah pimpinan Ketua Pengadilan Negeri. Untuk pelaksanaan eksekusi, maka pihak yang menang dalam perkara perdata harus membayar terlebih dahulu biaya pelaksanaan eksekusi. Dengan adanya ketentuan hukum berupa sanksi pidana bagi pihak yang kalah sebab tidak patuh terhadap putusan lembaga peradilan, maka pihak yang kalah akan memiliki kepatuhan hukum terhadap putusan pengadilan. Dengan demikian maka putusan dapat dilaksanakan secara sederhana dan cepat, serta pihak yang menang tidak perlu mengeluarkan biaya pelaksanaan eksekusi, sehingga terealisasi asas peradilan yang sederhana, cepat, dan biaya ringan. Ibid, hlm. 231.
} 


\section{DAFTAR PUSTAKA}

Agustina, Rosa, 2003, Perbuatan Melawan Hukum, Program Pasca Sarjana, Fakultas Hukum, Universitas Indonesia, Jakarta.

Allen, C.K., 1964, Law in the Making, Oxford University Press, New York.

Budiyono, Tri, 2009, Transplantasi Hukum, Harmonisasi, dan Potensi (Studi Transplantasi Doktrin yang Dikembangkan Dari Tradisi Common Law Pada Undang-Undang Perseroan Terbatas), Griya Media, Salatiga.

Djojodirdjo, M.A. Moegni, 1982, Perbuatan Melawan Hukum, Pradnya Paramita, Jakarta.

Fuady, Munir, 2005, Perbuatan Melawan Hukum (Pendekatan Kontemporer), Citra Aditya Bakti, Bandung.

Jing, Liu, 2013, Compensating Ecological Damage (Comparative and Economic Observations), Intersentia, Cambridge.

Keliat, Makmur et.al., 2016, Tanggung Jawab Negara, Friedrich Ebert Stiftung Kantor Perwakilan Indonesia, Jakarta.

Kelsen, Hans, 1949, General Theory of Law and State, Harvard University Press, Cambridge Massachusetts.

Khairandy, Ridwan, 2009, Perseroan Terbatas (Doktrin, Peraturan Perundang-undangan, dan Yurisprudensi), Kreasi Total Media, Yogyakarta.

Kusumaatmadja, Mochtar, 1975, Fungsi dan Perkembangan Hukum Dalam Pembangunan Nasional, Bina Cipta, Bandung.

Lotulung, Paulus Effendi, 1993, Penegakan Hukum Lingkungan Oleh Hakim Perdata, Citra Aditya Bakti, Bandung.

Machmud, Syahrul, 2012, Penegakan Hukum Lingkungan Indonesia (Penegakan Berdasarkan Hukum Administrasi, Hukum Perdata dan Hukum Pidana Menurut Undang-undang Nomor 32 Tahun 2009, Graha Ilmu, Medan.

Muladi, dan Dwidja Priyatno, 2011, Pertanggungjawaban Pidana Korporasi, Kencana Prenada Media Group, Jakarta.

Rahardjo, Satjipto, 2006, Ilmu Hukum, Citra Aditya Bakti, Bandung.

Rahmadi, Takdir, 2015, Hukum Lingkungan, Raja Grafindo Persada, Jakarta.

Rangkuti, Siti Sundari, 1996, Hukum Lingkungan dan Kebijaksanaan Lingkungan Nasional, Airlangga University Press, Surabaya.

Silalahi, M. Daud, 2001, Hukum Lingkungan Dalam Sistem Penegakan Hukum Lingkungan Indonesia, Alumni, Bandung.

Stewart, Richard, and James E. Krier, 1978, Environmental Law and Policy, The Bobbs Merril, Indianapolis, New York.

Syarif, Laode M., dan Andri G. Wibisana, 2010, Hukum Lingkungan (Teori, Legislasi, dan Studi Kasus), Raja Grafindo Persada, Jakarta.

Watson, Alan, 1993, Legal Transplants (An Approach to Comparative Law), University of Georgia Press, Athens.

Wibisana, Andri G., 2017, Penegakan Hukum Lingkungan (Melalui Pertanggungjawaban Perdata), Badan Penerbit Fakultas Hukum, Universitas Indonesia, Depok.

Undang-Undang Dasar Negara Republik Indonesia Tahun 1945.

Kitab Undang-Undang Hukum Perdata.

Undang-Undang Nomor 39 Tahun 1999 Tentang Hak Asasi Manusia.

Undang-Undang Nomor 25 Tahun 2007 Tentang Penanaman Modal.

Undang-Undang Nomor 40 Tahun 2007 Tentang Perseroan Terbatas.

Undang-Undang Nomor 32 Tahun 2009 Tentang Perlindungan dan Pengelolaan Lingkungan Hidup. 
Undang-Undang Nomor 48 Tahun 2009 Tentang Kekuasaan Kehakiman.

Undang-Undang Nomor 39 Tahun 2014 Tentang Perkebunan.

Peraturan Pemerintah Nomor 41 Tahun 1999 Tentang Pengendalian Pencemaran Udara.

Peraturan Pemerintah Nomor 4 Tahun 2001 Tentang Pengendalian Kerusakan dan/atau Pencemaran Lingkungan Hidup yang Berkaitan Dengan Kebakaran Hutan dan/atau Lahan.

Peraturan Pemerintah Nomor 47 Tahun 2012 Tentang Tanggung Jawab Sosial dan Lingkungan Perseroan Terbatas.

Peraturan Menteri Lingkungan Hidup Nomor 10 Tahun 2010 Tentang Mekanisme Pencegahan Pencemaran dan/atau Kerusakan Lingkungan Hidup yang Berkaitan Dengan Kebakaran Hutan dan/atau Lahan.

Peraturan Menteri Lingkungan Hidup Nomor 12 Tahun 2010 Tentang Pelaksanaan Pengendalian Pencemaran Udara di Daerah.

Peraturan Menteri Lingkungan Hidup Nomor 7 Tahun 2014 Tentang Kerugian Lingkungan Hidup Akibat Pencemaran dan/atau Kerusakan Lingkungan Hidup.

Surat Keputusan Ketua Mahkamah Agung Nomor 36/KMA/SK/II/2013 Tentang Pemberlakuan Pedoman Penanganan Perkara Lingkungan Hidup.

Naldo, Rony Andre Christian, 2021, Pertanggungjawaban Mutlak Korporasi Terhadap Kerugian Lingkungan Hidup (Studi Kasus Kebakaran Lahan Perkebunan di Pulau Sumatera), Disertasi, Program Studi Doktor Ilmu Hukum, Fakultas Hukum, Universitas Sumatera Utara, Medan.

Bohlen, Francis H., 1911, The Rule in Rylands v. Fletcher Part I, University of Pennsylvania Law Review and American Law Register, Volume 59, Philadelphia.

Faiz, Pan Mohamad, 2009, Teori Keadilan John Rawls (John Rawls' Theory of Justice), Jurnal Konstitusi, Volume 6, Nomor 1, Mahkamah Konstitusi, Jakarta.

Naldo, Rony Andre Christian, and Ningrum Natasya Sirait, 2017, Implementation of Corporate Absolute Responsibility for Land Fires Causing Air Pollution, Advances in Social Science, Education and Humanities Research, Volume 141, International Conference on Public Policy Social Computing and Development, Medan.

Ognall, Harry H., 1958, Some Facets of Strict Tortious Liability In The United States and Their Implications, Notre Dame Lawyer, Volume 33, Issue 2, Indiana.

Peck, Cornelius J., 1971, Negligence and Liability Without Fault in Tort Law, Washington Law Review, Volume 46, Issue 2, Washington.

Wibisana, Andri G., 2017, Keadilan Dalam Satu/Intra Generasi (Sebuah Pengantar Berdasarkan Taksonomi Keadilan Lingkungan), Jurnal Mimbar Hukum, Volume 29, Nomor 2, Fakultas Hukum, Universitas Gadjah Mada, Yogyakarta. 